\title{
Can pattern and depth of invasion predict lymph node relapse and prognosis in tongue squamous cell carcinoma
}

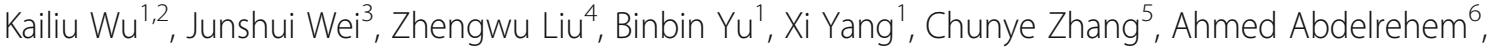 \\ Chenping Zhang ${ }^{1}$ and Siyi $\mathrm{Li}^{1,2^{*}}$ (D)
}

\begin{abstract}
Background: Tongue squamous cell carcinoma (TSCC) is a special type of oral cancer. Cervical lymph node relapse may occur in a large percentage of TSCC patients, which usually indicates poor prognosis. In this cohort study, we focused on the predictive value of the pathological features on cervical lymph node relapse and TSCC prognosis (disease free survival).
\end{abstract}

Methods: One hundred forty-one TSCC patients staged as $\mathrm{T}_{1-2} \mathrm{~N}_{0}$ were enrolled and categorized. Subjects were followed-up for 60 months. Univariate analysis was performed with Chi-square test for cervical lymph node relapse and Kaplan-Meier survival analysis and log rank $P$ value for patient prognosis; multivariate analysis was also utilized with Cox regression.

Results: In univariate analysis, trabes growth pattern, depth of invasion greater than $4 \mathrm{~mm}$, poor pathological differentiation and neurovascular invasion were considered as risk factors for cervical lymph node relapse and poor prognosis. In multivariate analysis, only patients with trabes growth pattern in the invasive front or depth of invasion larger than $4 \mathrm{~mm}$ had a higher risk of metastasis. Elder age group and trabes growth pattern of invasive front were considered as predictors of poor prognosis. Bad habits of smoking and alcohol consumption were related to the higher risk of metastasis.

Conclusion: Trabes growth pattern of invasive front was a potent risk factor for TSCC cervical lymph node relapse and indicated poor prognosis. Preventive therapy including selective neck dissection was thus suggested for certain patients.

Trial registration: Not applicable.

Keywords: Elective neck dissection, Head and neck cancer, Invasive front, Survival analysis, Prognosis, Cohort studies

\section{Background}

Globally, oral cancer is a huge threat to our health. Approximately 300,400 people were diagnosed and 145,400 died of oral cancer in a year [1]. Among all

\footnotetext{
* Correspondence: lisiyi_sjtu@yeah.net

'Shanghai Key Laboratory of Stomatology, Department of Oral and Maxillofacial-Head and Neck Oncology, Ninth People's Hospital, School of Stomatology, Shanghai Jiao Tong University School of Medicine, Shanghai 200011, China

2Department of Oral and Maxillofacial-Head and Neck Oncology, Fengcheng Hospital \& Shanghai Ninth People's Hospital (Fengcheng Branch Hospital) Affiliated to School of Medicine of Shanghai Jiao Tong University, Shanghai 201411, China

Full list of author information is available at the end of the article
}

types of oral cancer, squamous cell carcinoma (SCC) accounts for more than 95\%. Derived from stratified squamous epithelium of the oral mucosa, SCC primarily occurred at the buccal mucosa and tongue [2]. Tobacco, alcohol use, radiation and human papillary virus infection are implicated as risk factors for SCC [3].

Tongue squamous cell carcinoma (TSCC) is a special type of oral cancer. Patients may present with non-healing ulcers and pain in the mouth. TSCC usually grows as infiltrative and/or exophytic lesions and presents with local invasion. Dysarthria during the development of the disease implies the invasion of the tumor into the deep muscles. TSCC do not

(c) The Author(s). 2019 Open Access This article is distributed under the terms of the Creative Commons Attribution 4.0 International License (http://creativecommons.org/licenses/by/4.0/), which permits unrestricted use, distribution, and reproduction in any medium, provided you give appropriate credit to the original author(s) and the source, provide a link to the Creative Commons license, and indicate if changes were made. The Creative Commons Public Domain Dedication waiver (http://creativecommons.org/publicdomain/zero/1.0/) applies to the data made available in this article, unless otherwise stated. 
often have distant metastasis, but cervical lymph node relapse may occur in a large percentage of TSCC patients, which usually indicates poor prognosis. Analysis concerning the risk factors for cervical lymph node relapse is thus critical for clarifying the onset and progression of TSCC as well as improving the prognosis of patients. Few studies have been focusing on the clinical and pathological factors related to the prognosis of TSCC [4]. Yet few reports investigated the pathological features of TSCC.

It was established that tumor cells at the invasive front differed substantially from the central and superficial tumor cells. The invasive front of tumor often indicated the aggressiveness of TSCC [5]. In addition, the depth of invasion may also reflect the progression of tumor. Moreover, it was reported in esophageal tumors that the invasive front acted as predictive factors for metastasis and prognosis [6]. In this cohort study, using both univariate and multivariate analyses, we focused on the predictive value of the pathological features on cervical lymph node relapse and TSCC prognosis.

\section{Methods \\ Subjects}

Subjects involved in this study were recruited from the outpatient clinic at Shanghai Jiao Tong University School of Medicine. All patients were pathologically confirmed as TSCC by having biopsy before surgery and then staged as $\mathrm{T}_{1-2}$ with no cervical lymph node relapse $\left(\mathrm{N}_{0}\right)$. The TNM stage was evaluated by the clinical check and with the help of CT and B-ultrasound. TSCC samples were collected following tumor resection. No radiotherapy or chemotherapy had been performed before the collection of tumor samples. Baseline information including gender, age, pathological features of tumor, location of tumor (anterior, middle and posterior), habits of alcohol consumption and smoking, and treatment (neck dissection vs. observation) was documented. Pathological features of TSCC samples included the growth pattern of the invasive front (crumb vs. trabes), depth of invasion ( $<4 \mathrm{~mm}$ vs. $\geq 4 \mathrm{~mm}$ ), grade of pathological differentiation (well vs. Moderate/poor), and neurovascular invasion (yes vs. no). The growth pattern of the invasive front was determined by the pathologists at the hospital according to Rivera et al. [7]. This study was performed following the protocols approved by the Ethical Committee of Shanghai Jiao Tong University School of Medicine. An informed consent was signed by all participants in this clinical study.

\section{Therapy}

Patients enrolled in the current study were randomly divided into neck dissection group and observation group. An elective supraomohyoid neck dissection was performed for patients in the neck dissection group. In cases with TSCC recurrence and cervical lymph node relapse during the follow-up, a corresponding therapy was applied to patients according to their condition. Radical resection, chemotherapy and radiotherapy might be included.

\section{Follow-up}

The maximum follow-up duration was 60 months. During the follow-up period, patients were examined for tumor recurrence and cervical lymph node relapse every 3 months during the first 24 months, then every 6 months for the following 36 months. Examination included clinical inspection and CT or MRI. All nodal relapse patients were pathologically proven by surgical pathology.

\section{Data analysis}

In this study, we focused on the association between the clinicopathological features of TSCC and patient prognosis (disease free survival), in addition to collecting both the Disease specific survival (DSS) and the Disease free survival (DFS). Univariate analysis was performed with Chi-square test for cervical lymph node relapse and Kaplan-Meier survival analysis and $\log$ rank $P$ value for patient prognosis; multivariate analysis was performed with Cox regression. Variations including gender, age, pathological features of tumor, location of tumor, habits of drinking and smoking, and treatment were involved in the growth pattern. Odd ratio (OR), hazard ratio (HR) and their corresponding 95\% confidence interval (CI) were calculated to measure the association. SPSS software, version 17.0 (SPSS, Chicago, IL) was used for the analysis, with $P<0.05$ being significant.

\section{Results}

\section{Characteristics of subjects}

This is a cohort study concerning the association between clinicopathological features of tumor and TSCC prognosis. A total of 141 TSCC patients (75 males and 66 females) were enrolled in this study. The average age of patients was 55 years. Majority of tumors $(n=103)$ were located in the middle part of the tongue. Sixty patients were at T1 stage and 81 at T2. Neck dissection was performed in 69 patients, while 72 patients were categorized in the observation group. Concerning pathological features of TSCC, samples were categorized into crumb (islet-infiltrating cells with wide margins of invasion) and trabes (thin infiltrating cords), as presented in Fig. 1 . Seventy nine patients had an invasive front in the crumb pattern, while 62 in the trabes pattern. Ninety eight patients had a depth of invasion greater than 4 $\mathrm{mm}$. Neurovascular invasion was observed in 18 patients and only 48 patients have well differentiated tumors. Furthermore, 59 patients had the habit of smoking and 

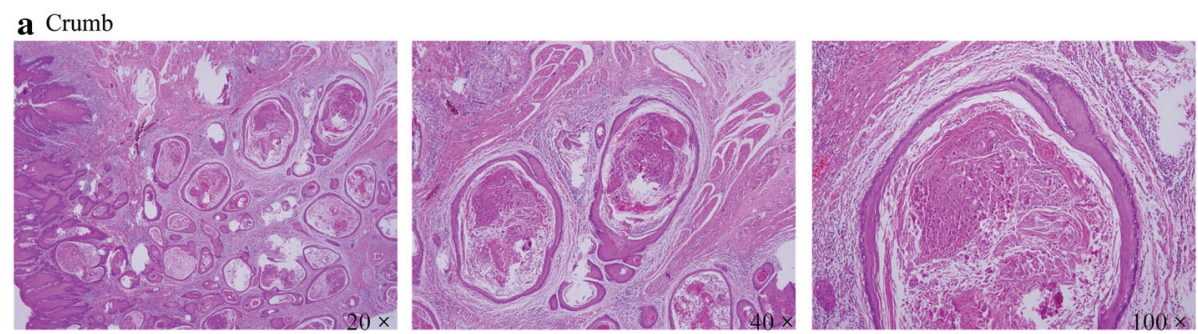

b Trabes
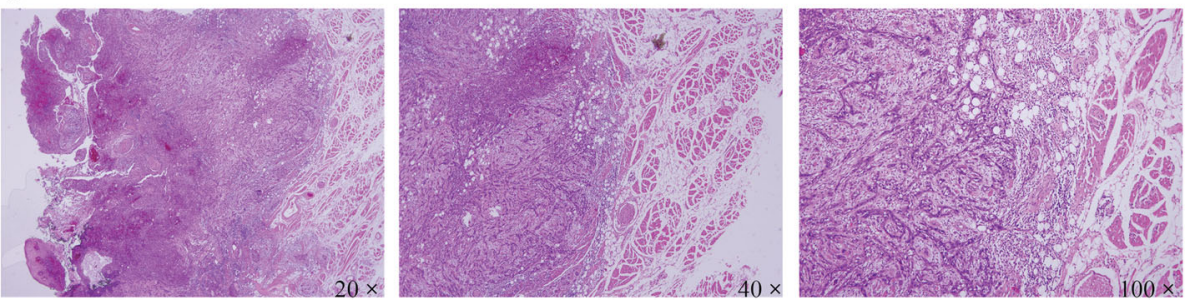

Fig. 1 Different pathological features of TSCC, crumb (islet-infiltrating cells with wide fronts of invasion) and trabes (thin infiltrating cords). a represents that the growth pattern of the invasion front invades the surrounding tissue like a rope, indicating a poor prognosis. $\mathbf{b}$ represents that the growth pattern of the invasion front advances like a clump forward, indicating a better prognosis relative to a

52 had the habit of drinking. The cervical lymph node relapse was observed in 36 patients. The average followup duration was 37 months. The results were summarized in Table 1. Patients with cervical lymph node relapse showed significantly altered pathological features including growth pattern of invasive front, depth of invasion, grade of pathological differentiation, and neurovascular invasion $(P<0.05)$. Moreover, location of the tumor, T stage, habit of drinking and smoking influenced the metastasis of TSCC $(P<0.05)$. However, patients with and without neck dissection had similar risk of cervical lymph node relapse $(P=0.191)$.

\section{Clinical features and lymph node relapse}

Subsequently, we investigated the association between clinicopathological features and cervical lymph node relapse with OR and corresponding 95\% CI. As illustrated in Table 2, trabes growth pattern was related to a higher risk of lymph node relapse (OR $=7.31,95 \% \mathrm{CI}$ : 3.01 17.72). Depth of invasion larger than $4 \mathrm{~mm}$, pattern of invasive front, poor pathological differentiation and neurovascular invasion were all considered as risk factors for cervical lymph node relapse $(\mathrm{OR}=23.33$, $\mathrm{OR}=2.65$, $\mathrm{OR}=6.16$ ). Furthermore, TSCC in the posterior region of the tongue indicated a high risk of metastasis as well $(\mathrm{OR}=9.29$, 95\%CI: 1.04-82.96). Moreover, Bad living habits including smoking and drinking increased the risk of cervical lymph node relapse $(\mathrm{OR}=2.47, \mathrm{OR}=3.34)$. Neck dissection did not significantly reduce the risk of metastasis $(\mathrm{OR}=1.66,95 \% \mathrm{CI}: 0.77-3.58)$.

However, in multivariate analysis, only growth pattern of invasive front and depth of invasion were observed to have significant effects on the status of cervical lymph node relapse. Patients with trabes growth pattern in the invasive front and depth of invasion larger than $4 \mathrm{~mm}$ had a higher risk of metastasis ( $\mathrm{OR}=5.03,95 \% \mathrm{CI}: 1.52$ 16.68; $\mathrm{OR}=12.23,95 \% \mathrm{CI}: 1.31-113.90)$.

\section{Clinical features and TSCC prognosis}

Considering the effect of clinicopathological features on TSCC prognosis, both univariate and multivariate analyses were performed. In Kaplan-Meier survival analysis, we found that the growth pattern of invasive front, depth of invasion, neurovascular invasion, location of the tumor, T stage, habit of smoking and drinking could significantly influence the prognosis of TSCC patients, as illustrated in Fig. $2(\log \operatorname{rank} P<0.05)$. The effect was measured with $\mathrm{HR}$ and corresponding $95 \% \mathrm{CI}$ as presented in Table 3. Cervical lymph node relapse also predicted poor prognosis $(\mathrm{HR}=72.29$, 95\%CI: 17.02307.07). However, according to our results, neck dissection did not help to improve the prognosis of TSCC patients significantly $(\mathrm{HR}=1.24,95 \% \mathrm{CI}: 0.60-2.58, P=$ $0.565)$.

In the multivariate analysis, the effect of clinical features on TSCC prognosis was analyzed with Cox regression. Age elder than 55 and trabes pattern of invasion were considered as predictors of poor prognosis $(\mathrm{HR}=$ 3.9, 95\%CI: 1.29-11.82; HR =6.3, 95\%CI: 1.15-34.43). Cervical lymph node relapse independent of other variations was also considered as a potent indicator for poor prognosis (HR $=36.7$; 95\%CI: 7.68-175.35).

According to our results, there was a strong correlation between the trabes growth pattern and DOI as illustrated in Table 4. 
Table 1 Baseline characteristics of the included tongue squamous cell carcinoma patients

\begin{tabular}{|c|c|c|c|c|}
\hline Items & Cases $(n=141)$ & Metastases $(+)$ & Metastases (-) & $P$ value $^{*}$ \\
\hline \multicolumn{5}{|l|}{ Gender } \\
\hline Male & 75 & 24 & 51 & \multirow[t]{2}{*}{0.061} \\
\hline Female & 66 & 12 & 54 & \\
\hline \multicolumn{5}{|l|}{ Age (years old) } \\
\hline$<55$ & 59 & 14 & 45 & \multirow[t]{2}{*}{0.678} \\
\hline$\geq 55$ & 82 & 22 & 60 & \\
\hline \multicolumn{5}{|c|}{ Growth mode of invasive front } \\
\hline Crumb & 79 & 8 & 71 & \multirow[t]{2}{*}{$<0.001$} \\
\hline Trabes & 62 & 28 & 34 & \\
\hline \multicolumn{5}{|l|}{ Depth of invasion } \\
\hline$<4 \mathrm{~mm}$ & 43 & 1 & 42 & \multirow[t]{2}{*}{$<0.001$} \\
\hline$\geq 4 \mathrm{~mm}$ & 98 & 35 & 63 & \\
\hline \multicolumn{5}{|c|}{ Pathological differentiation } \\
\hline Well & 48 & 7 & 41 & \multirow[t]{2}{*}{0.032} \\
\hline Moderate/poor & 93 & 29 & 64 & \\
\hline \multicolumn{5}{|c|}{ Neurovascular invasion } \\
\hline Yes & 18 & 11 & 7 & \multirow[t]{2}{*}{$<0.001$} \\
\hline No & 123 & 25 & 98 & \\
\hline \multicolumn{5}{|l|}{ Location } \\
\hline Anterior & 14 & 1 & 13 & \multirow[t]{3}{*}{0.053} \\
\hline Middle & 103 & 25 & 78 & \\
\hline Back & 24 & 10 & 14 & \\
\hline \multicolumn{5}{|l|}{ T stage } \\
\hline $\mathrm{T} 1$ & 60 & 8 & 52 & \multirow[t]{2}{*}{0.004} \\
\hline $\mathrm{T} 2$ & 81 & 28 & 53 & \\
\hline \multicolumn{5}{|l|}{ Smoking } \\
\hline Yes & 59 & 21 & 38 & \multirow[t]{2}{*}{0.02} \\
\hline No & 82 & 15 & 67 & \\
\hline \multicolumn{5}{|l|}{ Drinking } \\
\hline Yes & 52 & 21 & 31 & \multirow[t]{2}{*}{0.002} \\
\hline No & 89 & 15 & 74 & \\
\hline \multicolumn{5}{|l|}{ Treatment } \\
\hline Neck dissection & 69 & 21 & 48 & \multirow[t]{2}{*}{0.191} \\
\hline Observation & 72 & 15 & 57 & \\
\hline
\end{tabular}

$P^{*}$ : chi-square test

\section{Discussion}

The present study investigated the correlation between the clinicopathological features, cervical lymph node relapse and TSCC prognosis. Both univariate and multivariate analyses were performed. In the univariate analysis, trabes growth pattern, depth of invasion larger than $4 \mathrm{~mm}$, pattern of invasive front, poor pathological differentiation and neurovascular invasion were all considered as risk factors for cervical lymph node relapse. TSCC in the posterior tongue region and unfavorable habits of smoking and drinking were related to the higher risk of metastasis. However, in the multivariate analysis, only patients with trabes growth pattern in the invasive front and depth of invasion larger than $4 \mathrm{~mm}$ were found to have higher risk of metastasis. Similarly, concerning the prognosis of TSCC patients, in univariate analysis, trabes growth pattern of invasive front, depth of invasion larger than $4 \mathrm{~mm}$, neurovascular invasion, habits of smoking and drinking were associated with poor TSCC prognosis. In multivariate analysis, only 
Table 2 Univariate and multivariate analyses about parameters relevant to lymph node relapse

\begin{tabular}{|c|c|c|c|c|c|c|c|}
\hline \multirow[t]{2}{*}{ Items } & \multirow{2}{*}{$\begin{array}{l}\text { All } \\
\text { patients } \\
\text { (n) }\end{array}$} & \multirow{2}{*}{$\begin{array}{l}\text { With } \\
\text { lymph } \\
\text { node } \\
\text { relapse }\end{array}$} & \multirow{2}{*}{$\begin{array}{l}\text { Without } \\
\text { lymph } \\
\text { node } \\
\text { relapse }\end{array}$} & \multicolumn{2}{|l|}{ Univariate analysis } & \multicolumn{2}{|l|}{ Multi-variate analysis } \\
\hline & & & & OR $(95 \% \mathrm{Cl})$ & $P$ value $^{*}$ & OR $(95 \% \mathrm{Cl})$ & $P$ value\# \\
\hline \multicolumn{8}{|l|}{ Gender } \\
\hline Male & 75 & 24 & 51 & Reference & & Reference & \\
\hline Female & 66 & 12 & 54 & $0.47(0.21-1.04)$ & 0.063 & $0.64(0.15-2.69)$ & 0.541 \\
\hline \multicolumn{8}{|l|}{ Age (years old) } \\
\hline$<55$ & 59 & 14 & 45 & Reference & & Reference & \\
\hline$\geq 55$ & 82 & 22 & 60 & $1.18(0.54-2.56)$ & 0.677 & $1.23(0.45-3.34)$ & 0.683 \\
\hline \multicolumn{8}{|c|}{ Growth mode of invasive front } \\
\hline Crumb & 79 & 8 & 71 & Reference & & Reference & \\
\hline Trabes & 62 & 28 & 34 & $7.31(3.01-17.72)$ & 0.001 & $5.03(1.52-16.68)$ & 0.008 \\
\hline \multicolumn{8}{|l|}{ Depth of invasion } \\
\hline$<4 \mathrm{~mm}$ & 43 & 1 & 42 & Reference & & Reference & \\
\hline$\geq 4 \mathrm{~mm}$ & 98 & 35 & 63 & $23.33(3.08-176.91)$ & 0.002 & $12.23(1.31-113.90)$ & 0.028 \\
\hline \multicolumn{8}{|c|}{ Pathological differentiation } \\
\hline Well & 48 & 7 & 41 & Reference & & Reference & \\
\hline Moderate/poor & 93 & 29 & 64 & $2.65(1.06-6.62)$ & 0.036 & $0.76(0.22-2.62)$ & 0.667 \\
\hline \multicolumn{8}{|c|}{ Neurovascular invasion } \\
\hline No & 123 & 25 & 98 & Reference & & Reference & \\
\hline Yes & 18 & 11 & 7 & $6.16(2.17-17.51)$ & 0.001 & $2.20(0.61-7.97)$ & 0.232 \\
\hline \multicolumn{8}{|l|}{ Location } \\
\hline Anterior & 14 & 1 & 13 & Reference & & Reference & \\
\hline Middle & 103 & 25 & 78 & $4.17(0.52-33.46)$ & 0.179 & $5.05(0.52-49.44)$ & 0.164 \\
\hline Back & 24 & 10 & 14 & $9.29(1.04-82.96)$ & 0.046 & $5.74(0.50-66.52)$ & 0.162 \\
\hline \multicolumn{8}{|l|}{ T stage } \\
\hline $\mathrm{T} 1$ & 60 & 8 & 52 & Reference & & Reference & \\
\hline $\mathrm{T} 2$ & 81 & 28 & 53 & $3.43(1.43-8.23)$ & 0.006 & $1.42(0.46-4.35)$ & 0.543 \\
\hline \multicolumn{8}{|l|}{ Smoking } \\
\hline No & 82 & 15 & 67 & Reference & & Reference & \\
\hline Yes & 59 & 21 & 38 & $2.47(1.14-5.35)$ & 0.022 & $0.05(0.00-2.00)$ & 0.11 \\
\hline \multicolumn{8}{|l|}{ Drinking } \\
\hline No & 89 & 15 & 74 & Reference & & Reference & \\
\hline Yes & 52 & 21 & 31 & $3.34(1.53-7.32)$ & 0.003 & $33.62(0.97-1169.50)$ & 0.052 \\
\hline \multicolumn{8}{|l|}{ Treatment } \\
\hline Observation & 72 & 15 & 57 & Reference & & Reference & \\
\hline Neck dissection & 69 & 21 & 48 & $1.66(0.77-3.58)$ & 0.193 & $1.15(0.41-3.26)$ & 0.794 \\
\hline
\end{tabular}

OR odds ratio, $C l$ confidence interval; $P^{*}$ : uni-variate regression analysis; $P \#$ : multi-variate regression analysis. Note: entries in boldface means: $P<0.05$

elder age and trabes growth pattern of invasive front were considered as predictors of poor prognosis.

As previously reported, the average age of oral cancer was 63 years old [8]. In addition, elderly males usually suffered a higher risk of TSCC. In the current study, we observed that age was not significantly associated with cervical lymph node relapse both in univariate and multivariate analyses. However, age may serve as a critical predictor for the prognosis of TSCC. Old patients diagnosed at an age elder than 55 had significantly poorer prognosis compared with younger group.
Growth pattern of the tumor, depth of invasion, pathological differentiation and neurovascular invasion all indicated the aggressiveness of the tumor. Here in the univariate analysis, they were all proved to be risk factors for TSCC metastasis. However, some of such factors might be dependent on others. Hence a multivariate analysis was performed to clarify the independent risk factors. In the cox regression analysis, adjusted by gender, age, pathological features of tumor, location of tumor and treatment, trabes type of invasive front and depth of invasion greater than $4 \mathrm{~mm}$ were confirmed to 


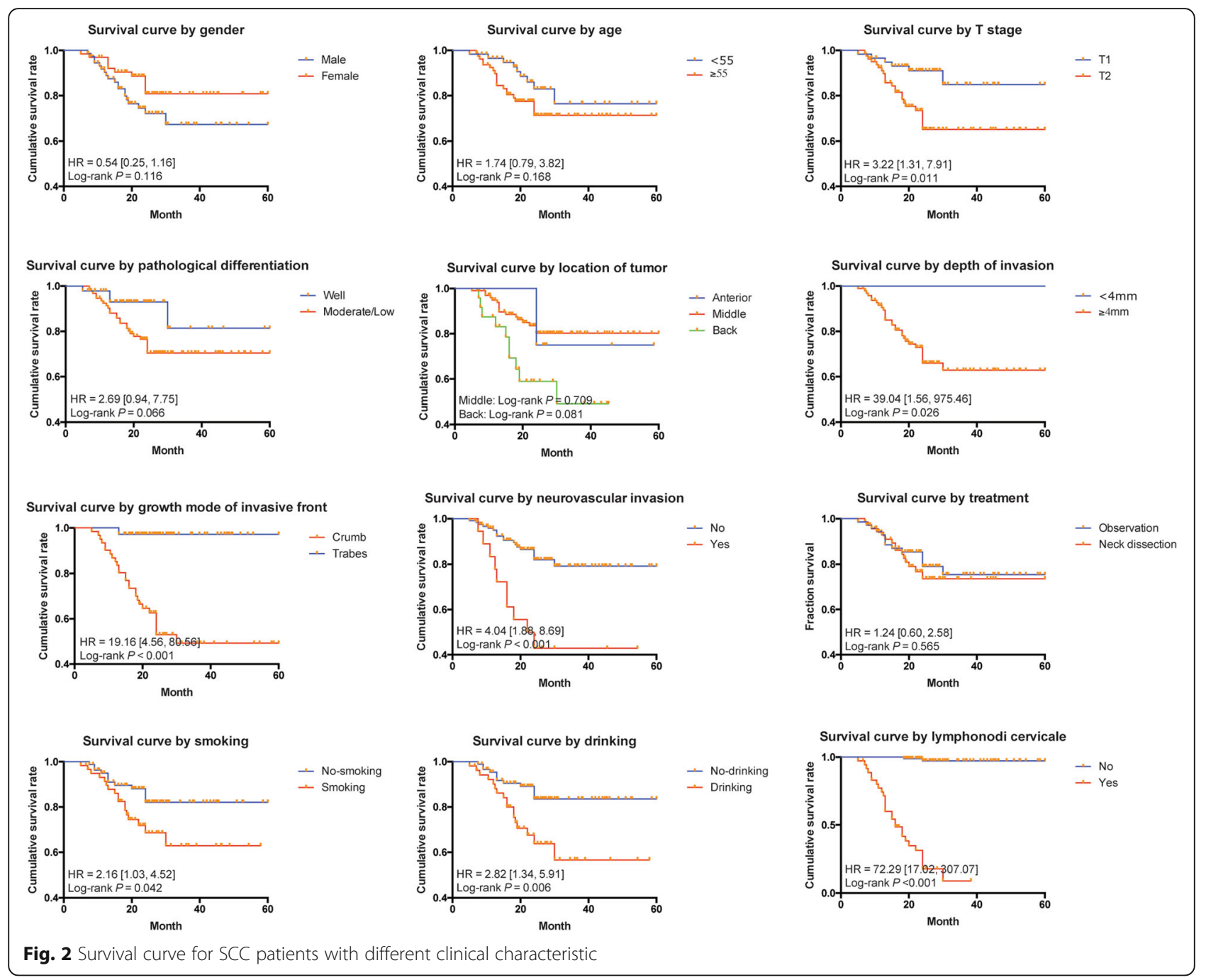

be independent predictors of TSCC cervical lymph node relapse.

In the study, the growth pattern of TSCC invasive front was classified as crumb (islet-infiltrating cells with wide fronts of invasion) or trabes (thin infiltrating cords) . A third pattern with individual infiltrating cells has also been reported previously in literature [7]. However, such growth pattern was not observed in our samples. As early as in 1984, Yamamoto et al. presented that oral cavity SCC with cord-like type (i.e. trabes) of invasive front showed a higher risk of metastasis [9], which is further confirmed with the results shown our research. Concerning the depth of tumor invasion, our results were in accordance with previous studies, which proposed a cut-off value at $5 \mathrm{~mm}$ of tumor depth $[10,11]$. Yet according to our results, metastasis was indicated in patients with the depth of invasion larger than $4 \mathrm{~mm}$, in consistence with Ambrosch et al. [12]. Moreover, an anatomical invasion of tumor deeper than the intrinsic tongue muscles, paralingual and sublingual spaces, and medial and lateral extrinsic tongue muscles, was a potent indicator of cervical lymph node relapse in TSCC [13]. The effect of neurovascular invasion and histological differentiation on cervical lymph node relapse has been widely investigated in SCC [14, 15]. In our results, neither neurovascular invasion nor histological differentiation was confirmed as independent predictors of cervical lymph node relapse in TSCC. We also found that cervical lymph node relapse is the most important prognostic factor in SCC with the highest HR value in multivariate analysis.

In the results of the current study, we also observed that neck dissection did not influence the metastasis and prognosis of TSCC. Results were contradictive concerning the effect of neck dissection on TSCC patients. Some suggested that neck dissection significantly reduces the mortality and increases the 5-year disease-free survival [16-18]. Yet some proposed that neck dissection is not necessary until a node is detectable [19]. Currently, in the treatment of TSCC, an 
Table 3 Univariate and multivariate analyses on factors associated with TSCC prognosis

\begin{tabular}{|c|c|c|c|c|c|c|c|}
\hline \multirow[t]{2}{*}{ Items } & \multirow[t]{2}{*}{$\mathrm{N}$} & \multicolumn{3}{|c|}{ Univariate analysis } & \multicolumn{3}{|c|}{ Multi-variate analysis } \\
\hline & & $\overline{\mathrm{HR}}$ & $95 \% \mathrm{Cl}$ & $P$ value & $\overline{\mathrm{HR}}$ & $95 \% \mathrm{Cl}$ & $P$ value $^{\#}$ \\
\hline \multicolumn{8}{|l|}{ Gender } \\
\hline Male & 75 & Reference & & & Reference & & \\
\hline Female & 66 & 0.54 & $0.25-1.16$ & 0.116 & 0.33 & $0.06-1.79$ & 0.201 \\
\hline \multicolumn{8}{|l|}{ Age (years old) } \\
\hline$<55$ & 59 & Reference & & & Reference & & \\
\hline$\geq 55$ & 82 & 1.74 & $0.79-3.82$ & 0.168 & 3.9 & $1.29-11.82$ & 0.016 \\
\hline \multicolumn{8}{|c|}{ Growth mode of invasive front } \\
\hline Crumb & 79 & Reference & & & Reference & & \\
\hline Trabes & 62 & 19.16 & $4.56-80.56$ & $<0.001$ & 6.3 & $1.15-34.43$ & 0.034 \\
\hline \multicolumn{8}{|l|}{ Depth of invasion } \\
\hline$<4 \mathrm{~mm}$ & 43 & Reference & & & Reference & & \\
\hline$\geq 4 \mathrm{~mm}$ & 98 & 39.04 & $1.56-975.46$ & 0.026 & $237,144.33$ & $0.00-8.820 E+118$ & 0.926 \\
\hline \multicolumn{8}{|c|}{ Pathological differentiation } \\
\hline Well & 48 & Reference & & & Reference & & \\
\hline Moderate/poor & 93 & 2.69 & $0.94-7.75$ & 0.066 & 0.913 & $0.20-4.09$ & 0.905 \\
\hline \multicolumn{8}{|c|}{ Neurovascular invasion } \\
\hline No & 123 & Reference & & & Reference & & \\
\hline Yes & 18 & 4.04 & $1.88-8.69$ & $<0.001$ & 0.48 & $0.19-1.24$ & 0.129 \\
\hline \multicolumn{8}{|l|}{ Location } \\
\hline Anterior & 14 & Reference & & & Reference & & \\
\hline Middle & 103 & 1.32 & $0.31-5.73$ & 0.709 & 2.51 & $0.45-14.03$ & 0.296 \\
\hline Back & 24 & 3.87 & $0.85-17.68$ & 0.081 & 4.66 & $0.62-35.02$ & 0.135 \\
\hline \multicolumn{8}{|l|}{ T stage } \\
\hline $\mathrm{T} 1$ & 60 & Reference & & & Reference & & \\
\hline $\mathrm{T} 2$ & 81 & 3.22 & $1.31-7.91$ & 0.011 & 1.23 & $0.35-4.32$ & 0.752 \\
\hline \multicolumn{8}{|l|}{ Smoking } \\
\hline No & 82 & Reference & & & Reference & & \\
\hline Yes & 59 & 2.16 & $1.03-4.52$ & 0.042 & 0.00 & $0.00-2.917 \mathrm{E}+078$ & 0.929 \\
\hline \multicolumn{8}{|l|}{ Drinking } \\
\hline No & 89 & Reference & & & Reference & & \\
\hline Yes & 52 & 2.82 & $1.34-5.91$ & 0.006 & 2162.96 & $0.00-3.651 \mathrm{E}+085$ & 0.937 \\
\hline \multicolumn{8}{|l|}{ Treatment } \\
\hline Observation & 72 & Reference & & & Reference & & \\
\hline Neck dissection & 69 & 1.24 & $0.60-2.58$ & 0.565 & 0.96 & $0.40-2.30$ & 0.922 \\
\hline \multicolumn{8}{|c|}{ Lymphonodi cervicale } \\
\hline No & 105 & Reference & & & Reference & & \\
\hline Yes & 36 & 72.29 & $17.02-307.07$ & $<0.001$ & 36.7 & $7.68-175.35$ & $<0.001$ \\
\hline
\end{tabular}

HR hazard ratio, $\mathrm{Cl}$ confidence interval; $P^{*}$ : uni-variate regression analysis; $P^{\sharp}$ : multi-variate regression analysis. Note: entries in boldface means: $P<0.05$

elective neck dissection is suggested only for patients with certain risk factors, as Fakih et al. proposed in their research [20]. Hence, for patients with risk factors including trabes invasive front and depth of tumor greater than 4 $\mathrm{mm}$, an elective neck dissection is suggested to improve the prognosis of these patients.
Effects of alcohol drinking and smoking on TSCC was also evaluated in this study. Drinking and smoking have been regarded as risk factors for TSCC [4]. According to our results, in univariate analysis, both smoking and drinking were correlated with cervical lymph node relapse and poor prognosis. However, the effect was not 
Table 4 Chi-square test analyses on pattern and DOI

\begin{tabular}{llllll}
\hline Pattern & DOI & & Lymph & \multicolumn{2}{l}{ Chi-square test } \\
\cline { 2 - 3 } & $<4 \mathrm{~mm}$ & $>=4 \mathrm{~mm}$ & Node & OR (95\%Cl) & P Value \\
\hline Crumb & 34 & 37 & Relapse(-) & $2.986(1.191-7.487)$ & 0.017 \\
Trabes & 8 & 26 & & & \\
Crumb & 2 & 14 & Relapse(+) & $11.4(1.105-117.7)$ & 0.013 \\
Trabes & 0 & 56 & & & \\
Crumb & 36 & 51 & Total & $7.235(3.117-16.794)$ & $<0.001$ \\
Trabes & 8 & 82 & & & \\
\hline
\end{tabular}

significant in multivariate analysis adjusted by gender, age, pathological features of tumor, location of tumor and treatment. Similarly, in the report of Wildt et al., tobacco smoking, but not alcohol consumption, was observed to have significant influences on the prognosis in the Cox proportional hazards regression analysis, with $\mathrm{T}$-stage, $\mathrm{N}$-stage, clinical stage, tumor size and gender of patients as adjusted variables [21]. Moreover, it was reported that the alcohol consumption and smoking were related to the location of SCC. Tobacco smoking was correlated with a higher risk of malignancy in the retromolar area and floor of the mouth, while more SCC in the floor of mouth and tongue was observed in patients with habit of drinking [22]. Yet in our study, we failed to observe a similar result.

\section{Conclusions}

In this cohort study, 141 TSCC patients were enrolled for the analysis of the clinicopathological features, cervical lymph node relapse and TSCC prognosis. In multivariate analysis, we identified the trabes growth pattern in the invasive front and depth of invasion larger than 4 $\mathrm{mm}$ as risk factors for cervical lymph node relapse. Concerning TSCC prognosis, only elder age group and trabes growth pattern of invasive front were considered as indicators for poor prognosis. Hence we suggested that preventive therapy for the cervical lymph node relapse, such as elective neck dissection, should be performed on patients with trabes growth pattern in the invasive front and depth of tumor invasion greater than $4 \mathrm{~mm}$.

\section{Abbreviations}

Cl: Confidence interval; DFS: The Disease free survival; DSS: The Disease specific survival; HR: Hazard ratio; OR: Odd ratio; SCC: Squamous cell carcinoma; TSCC: Tongue squamous cell carcinoma

\section{Acknowledgments}

None.

\section{Authors' contributions}

Contributing to the conception and design of the work: KW, JW, ZL, BY, XY; Analysis and interpretation of data: KW, JW, LZ, ChunZ, AA, ChenZ; Drafting the manuscript: BY, XY, ChunZ, AA, ChenZ, SL; Revising it critically for important intellectual content: SL; Approving the final version to be published: All authors.

\section{Funding}

This work was supported by research Grant No 20151005 from Shanghai Science and Technology Commission and by research Grant No 201540257 from Shanghai Health Development Planning Commission. The fund is mainly used for the acquisition of information, experimental instruments and data analysis software copyright purchase.

\section{Availability of data and materials}

The datasets used and analyzed during the current study are available from the corresponding author on reasonable request.

\section{Ethics approval and consent to participate}

All procedures performed in the study involving human participants were in compliance with the Helsinki Declaration and Shanghai Jiao Tong University School of Medicine (Approval Number: $\mathrm{SH} 9 \mathrm{H}-2008-023-1)$. Written informed consent was obtained from all individual participants included in the study.

Consent for publication

Not applicable.

\section{Competing interests}

The authors declare that they have no competing interests.

\section{Author details}

${ }^{1}$ Shanghai Key Laboratory of Stomatology, Department of Oral and Maxillofacial-Head and Neck Oncology, Ninth People's Hospital, School of Stomatology, Shanghai Jiao Tong University School of Medicine, Shanghai 200011, China. ${ }^{2}$ Department of Oral and Maxillofacial-Head and Neck Oncology, Fengcheng Hospital \& Shanghai Ninth People's Hospital (Fengcheng Branch Hospital) Affiliated to School of Medicine of Shanghai Jiao Tong University, Shanghai 201411, China. ${ }^{3}$ Department of Stomatology, Taizhou First People's Hospital, Taizhou 318020, China. ${ }^{4}$ Department of Oral and Maxillofacial Surgery, Third Attached Hospital, Guangxi Medical University, Nanning 530031, China. ${ }^{5}$ Shanghai Key Laboratory of

Stomatology, Department of oral pathology, Ninth People's Hospital, School of Stomatology, Shanghai Jiao Tong University School of Medicine, Shanghai 200011, China. ${ }^{6}$ Lecturer, Department of Craniomaxillofacial and Plastic

Surgery, Faculty of Dentistry, Alexandria University, Alexandria, Egypt.

Received: 26 November 2018 Accepted: 20 June 2019

Published online: 19 July 2019

\section{References}

1. Torre LA, Bray F, Siegel RL, Ferlay J, Lortet-Tieulent J, Jemal A. Global cancer statistics, 2012. CA Cancer J Clin. 2015;65(2):87-108.

2. Jerjes W, Upile T, Petrie A, Riskalla A, Hamdoon Z, Vourvachis M, Karavidas K, Jay A, Sandison A, Thomas GJ, et al. Clinicopathological parameters, recurrence, locoregional and distant metastasis in 115 T1-T2 oral squamous cell carcinoma patients. Head Neck Oncol. 2010;2:9.

3. Warnakulasuriya S. Global epidemiology of oral and oropharyngeal cancer. Oral Oncol. 2009;45(4-5):309-16.

4. Massano J, Regateiro FS, Januario G, Ferreira A. Oral squamous cell carcinoma: review of prognostic and predictive factors. Oral Surg Oral Med Oral Pathol Oral Radiol Endod. 2006;102(1):67-76.

5. Bankfalvi A, Piffko J. Prognostic and predictive factors in oral cancer: the role of the invasive tumour front. J Oral Pathol Med. 2000:29(7):291-8.

6. Miyata H, Yoshioka A, Yamasaki M, Nushijima Y, Takiguchi S, Fujiwara Y, Nishida T, Mano M, Mori M, Doki Y. Tumor budding in tumor invasive front predicts prognosis and survival of patients with esophageal squamous cell carcinomas receiving neoadjuvant chemotherapy. Cancer. 2009;115(14): 3324-34

7. Rivera C, Venegas B. Histological and molecular aspects of oral squamous cell carcinoma (review). Oncol Lett. 2014:8(1):7-11.

8. Ries LAG, Harkins D, Krapcho M, Mariotto A, Miller BA, Feuer EJ, Clegg LX, Eisner MP, Horner M-J, Howlader N. SEER cancer statistics review, 1975-2003; 2006.

9. Yamamoto E, Miyakawa A, Kohama G. Mode of invasion and lymph node metastasis in squamous cell carcinoma of the oral cavity. Head Neck Surg. 1984;6(5):938-47. 
10. Fukano $H$, Matsuura $H$, Hasegawa $Y$, Nakamura S. Depth of invasion as a predictive factor for cervical lymph node metastasis in tongue carcinoma. Head Neck. 1997;19(3):205-10.

11. Kane SV, Gupta M, Kakade AC, Cruz AD'. Depth of invasion is the most significant histological predictor of subclinical cervical lymph node metastasis in early squamous carcinomas of the oral cavity. Eur J Surg Oncol. 2006;32(7):795-803.

12. Ambrosch $P$, Kron M, Fischer G, Brinck U. Micrometastases in carcinoma of the upper aerodigestive tract: detection, risk of metastasizing, and prognostic value of depth of invasion. Head Neck. 1995;17(6):473-9.

13. Mitani S, Tomioka T, Hayashi R, Ugumori T, Hato N, Fujii S. Anatomic invasive depth predicts delayed cervical lymph node metastasis of tongue squamous cell carcinoma. Am J Surg Pathol. 2016:40(7):934-42.

14. Rahima B, Shingaki S, Nagata M, Saito C. Prognostic significance of perineural invasion in oral and oropharyngeal carcinoma. Oral Surg Oral Med Oral Pathol Oral Radiol Endod. 2004;97(4):423-31.

15. Fagan JJ, Collins B, Barnes L, D'Amico F, Myers EN, Johnson JT. Perineural invasion in squamous cell carcinoma of the head and neck. Arch Otolaryngol Head Neck Surg. 1998;124(6):637-40.

16. Feng Z, Li JN, Li CZ, Guo CB. Elective neck dissection versus observation in the management of early tongue carcinoma with clinically node-negative neck: a retrospective study of 229 cases. J Craniomaxillofac Surg. 2014;42(6): 806-10.

17. Ren ZH, Xu JL, Li B, Fan TF, Ji T, Zhang CP. Elective versus therapeutic neck dissection in node-negative oral cancer: evidence from five randomized controlled trials. Oral Oncol. 2015;51(11):976-81.

18. Fasunla AJ, Greene BH, Timmesfeld N, Wiegand S, Werner JA, Sesterhenn AM. A meta-analysis of the randomized controlled trials on elective neck dissection versus therapeutic neck dissection in oral cavity cancers with clinically node-negative neck. Oral Oncol. 2011;47(5):320-4.

19. Vandenbrouck C, Sancho-Garnier H, Chassagne D, Saravane D, Cachin Y, Micheau C. Elective versus therapeutic radical neck dissection in epidermoid carcinoma of the oral cavity: results of a randomized clinical trial. Cancer. 1980;46(2):386-90

20. Fakih AR, Rao RS, Borges AM, Patel AR. Elective versus therapeutic neck dissection in early carcinoma of the oral tongue. Am J Surg. 1989;158(4): 309-13.

21. Bundgaard T, Bentzen SM, Wildt J. The prognostic effect of tobacco and alcohol consumption in intra-oral squamous cell carcinoma. Eur J Cancer B Oral Oncol. 1994;30b(5):323-8.

22. Jovanovic A, Schulten EA, Kostense PJ, Snow GB, van der Waal I. Tobacco and alcohol related to the anatomical site of oral squamous cell carcinoma. J Oral Pathol Med. 1993;22(10):459-62.

\section{Publisher's Note}

Springer Nature remains neutral with regard to jurisdictional claims in published maps and institutional affiliations.

Ready to submit your research? Choose BMC and benefit from:

- fast, convenient online submission

- thorough peer review by experienced researchers in your field

- rapid publication on acceptance

- support for research data, including large and complex data types

- gold Open Access which fosters wider collaboration and increased citations

- maximum visibility for your research: over $100 \mathrm{M}$ website views per year

At $\mathrm{BMC}$, research is always in progress.

Learn more biomedcentral.com/submissions 